\title{
Trace elements in the whale shark Rhincodon typus liver: an indicator of the health status of the ecosystem base (plankton)
}

\author{
Francesca Pancaldi $^{1}(\mathbb{D})$, Ana J. Marmolejo-Rodríguez ${ }^{1}(\mathbb{D})$, Martin F. Soto-Jiménez ${ }^{2}$ \\ Daniela A. Murillo-Cisneros ${ }^{1}(\mathbb{D})$, Edgar E. Becerril-García ${ }^{1}{ }^{(D}$, Darren A. Whitehead ${ }^{1}$ \\ Rogelio González-Armas $^{1}(\mathbb{D})$, Felipe Galván-Magaña ${ }^{1} \mathbb{D}$ \& Federico Páez-Osuna ${ }^{2,3}$ \\ ${ }^{1}$ Centro Interdisciplinario de Ciencias Marinas, Instituto Politécnico Nacional \\ La Paz, Baja California Sur, Mexico \\ ${ }^{2}$ Unidad Académica Mazatlán, Instituto de Ciencias del Mar y Limnología \\ Universidad Nacional Autónoma de México, Mazatlán, Sinaloa, Mexico \\ ${ }^{3}$ El Colegio de Sinaloa, Culiacán, Sinaloa, Mexico \\ Corresponding author: Federico Páez-Osuna (paezos@ola.icmyl.unam.mx)
}

\begin{abstract}
Trace elements were determined in three areas of the right (RL) and left (LL) lobe of the liver obtained from a whale shark (Rhincodon typus) stranded in Mexico. Mean \pm standard error concentrations in $\mu \mathrm{g}$ $\mathrm{g}^{-1}$ wet weight were for zinc (Zn) RL: $22.5 \pm 2.1$; LL: $26.5 \pm 7.1$, arsenic (As) RL: $33.0 \pm 1.6$; LL: $20.0 \pm 9.9$ and cadmium (Cd) RL: $15.5 \pm 0.9$; LL: $11.3 \pm 3.7$; copper $(\mathrm{Cu}) \mathrm{RL}: 3.2 \pm 0.3$; LL: $2.2 \pm 0.8$, selenium (Se) RL: $0.5 \pm 0.1$; LL: $1.2 \pm 0.6$, mercury (Hg) RL: $0.06 \pm 0.02$; LL: $0.05 \pm 0.004$ and lead $(\mathrm{Pb}) \mathrm{RL}: 0.05 \pm 0.02$; LL: $0.05 \pm 0.01$. Concentrations showed significant $(P<0.05)$ differences within the same lobe but not between lobes. The trace element levels found in this whale shark represent the baseline levels of the trophic base's health status in the study area.
\end{abstract}

Keywords: Rhincodon typus; arsenic; mercury; selenium; cadmium molar ratio; Gulf of California

The liver is a highly metabolic organ where up taking, storing, and excretion of nutrients and other molecules occur (Hinton et al. 2001). Several studies describe this organ as a target for toxic substances (Pethybridge et al. 2010), as bioaccumulation of contaminants often occurs due to the large blood supply and its interaction with anthropogenic compounds as heavy metals and methylmercury (Bosch et al. 2016). One of the liver's primary functions is detoxification through the transformation of poorly excretable chemicals into more excretable ones, and the synthesize of metallothionine proteins that bind to different metals (Hinton et al. 2001). Therefore, the liver plays a key role in an organism's health. Top predators with large lipid-rich livers, such as most sharks, are particularly susceptible to the uptake and bioaccumulation of contaminants (Barrera-García et al. 2013), which can increase throughout their lifetime. Bioaccumulation occurs differentially between organs and tissues in a process known as organotropism (Correa et al. 2014), where specific organs are the main storage and detoxification sites of trace elements (Mieiro et al. 2011). The interaction between different elements is an additional tool for body detoxification. For example, selenium Se is an essential element that maintains cellular oxidative homeostasis and mitigates the toxicity of heavy metals such as mercury $\mathrm{Hg}$ (Endo et al. 2005) and cadmium Cd (Jamwal et al. 2018) through the action of selenoproteins (Belzile et al. 2006).

The whale shark Rhincodon typus is a circumglobal species found in several Gulf of California areas (Ketchum et al. 2013). It is a long-lived animal with a life span of more than 100 years; additionally, it is an opportunistic filter-feeding shark (Colman 1997). Feeding aggregations in the Gulf of California show that whale sharks prey mostly on zooplankton patches that are rich in copepods (Nelson \& Eckert 2007), euphausiids (Ketchum et al. 2013), and chaetognaths

Corresponding editor: Federico Cortés 
(Pancaldi et al. 2019b). Studies on trace elements bioaccumulation in this species are scarce and show that whale sharks accumulate arsenic As, $\mathrm{Hg}, \mathrm{Cd}$, copper $\mathrm{Cu}$, lead $\mathrm{Pb}$, selenium, and zinc $\mathrm{Zn}$ in the liver (Wang et al. 2015, Pancaldi et al. 2019a). This study complements a report on the element's concentrations in this animal's tissues (Pancaldi et al. 2019a, Whitehead et al. 2019). The main objectives of this study were to examine the concentrations of essential $(\mathrm{Cu}, \mathrm{Se}, \mathrm{Zn})$ and non-essential $(\mathrm{As}, \mathrm{Cd}, \mathrm{Hg}$ and $\mathrm{Pb})$ elements as well as to determine the potential antagonism between $\mathrm{Se}, \mathrm{Zn}, \mathrm{Hg}, \mathrm{Cd}$ and $\mathrm{As}$ throughout the molar ratio in three areas (proximal, median and distal) of the right and left lobes of the liver in a stranded whale shark from La Paz, Gulf of California, Mexico. Our results are also compared with heavy metal limits established for edible fish by the Food and Agriculture Organization (FAO) (CODEX 2009).

On February 16, 2018, a whale shark was found stranded inside $\mathrm{La}$ Paz Bay Lagoon $\left(24^{\circ} 4.8^{\prime} \mathrm{N}\right.$, $110^{\circ} 10.8^{\prime}$ W; Fig. 1), Baja California Sur, Mexico. The dead shark was immediately transported to a laboratory where the liver was extracted. Duplicate samples from the proximal, median, and distal part of both lobes of the liver were taken with a sterilized knife and preserved at $-20^{\circ} \mathrm{C}$ in plastic containers previously cleaned and rinsed with $\mathrm{HCl}(10 \%)$ and $\mathrm{HNO}_{3}(20 \%)$ for three days; subsequently, they were freeze-dried $\left(72 \mathrm{~h},-49^{\circ} \mathrm{C}\right.$ and $\left.133 \times 10^{-3} \mathrm{mbar}\right)$, pulverized and homogenized. Lyophilized aliquots $(0.25 \mathrm{~g})$, blanks, and reference material were digested in Teflon vials with caps (Savillex) using concentrated $\mathrm{HNO}_{3}(70 \%$, trace metal analysis, JT Baker) and $\mathrm{H}_{2} \mathrm{O}_{2}$ to $120^{\circ} \mathrm{C}$ for $4 \mathrm{~h}$. Digested samples were gauged with a solution of In 115 (Pancaldi et al. 2019a,b). The humid percentages of tissues are shown in Table 1. Mexican wildlife authorities approved ethics requirements and protocols for samples' obtention (SGPA/DGVS 05605/17).

Trace element analyses $(\mathrm{Cu}, \mathrm{Se}, \mathrm{Zn}, \mathrm{Hg}, \mathrm{As}, \mathrm{Cd}$, and $\mathrm{Pb}$ ) were performed using a high resolution inductively coupled plasma mass spectrometer (HR-ICP-MS) Thermo Scientific Element 2XR and cold vapor atomic absorption spectrometry (Pancaldi et al. 2019a,b). Quality control of the analysis included blanks and certified reference material (DOLT-5 dogfish liver). Blanks were performed with no anomalies detected. Recovery percentages were $112 \% \mathrm{Cu}, 105 \% \mathrm{Se}, 101 \%$ $\mathrm{Zn}, 92 \% \mathrm{As}, 106 \% \mathrm{Hg}$ and $100 \% \mathrm{Cd}$ and $\mathrm{Pb}$. Trace element concentrations are expressed on wet weight (ww). Non-parametric tests were used as data did not follow a normal distribution. Mann-Whitney test was applied to the mean concentrations between lobes, Kruskal Wallis and Dunn test was applied between mean concentrations of an element within the same lobe;

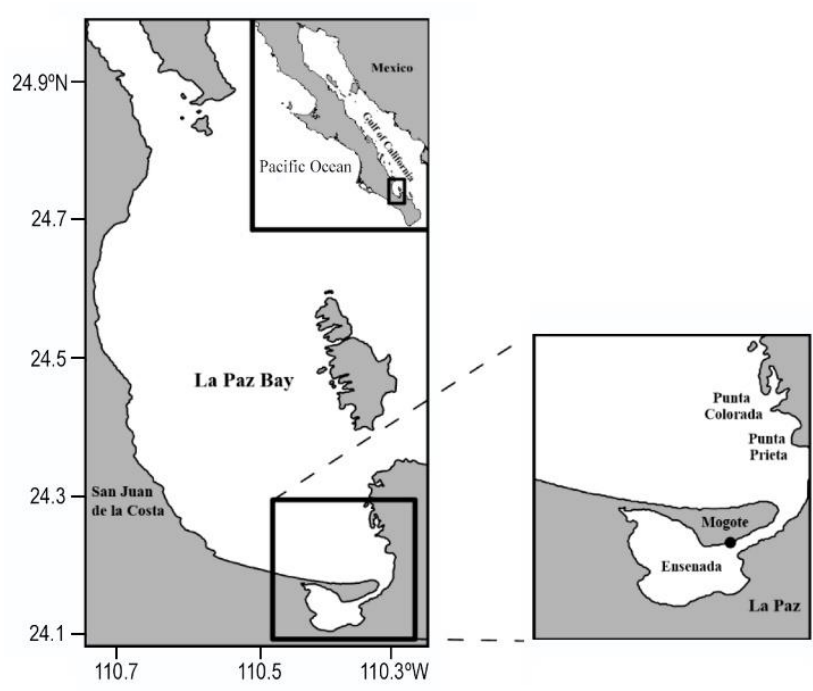

Figure 1. Map of La Paz Bay with a close up to La Paz Lagoon and the whale shark's (Rhincodon typus) feeding area (Mogote) (dark dot indicates the site where the stranded whale shark was found).

$t$-test was applied to the molar ratios to assess differences greater than 1 .

The stranded whale shark measured $548 \mathrm{~cm}$ in total length (TL), and it was identified as an immature male (Whitehead et al. 2019). The liver's right lobe (Fig. 2) measured $152 \mathrm{~cm}$ TL and $38 \mathrm{~cm}$ in its wider area. The gallbladder was attached to the right lobe near the proximal area. The left lobe of the liver measured 151 $\mathrm{cm}$ TL and $39 \mathrm{~cm}$ in its wider area. In general, As, Zn and $\mathrm{Cd}$ showed the highest concentrations in both lobes, while $\mathrm{Cu}, \mathrm{Hg}$, and $\mathrm{Pb}$ were the less concentrated elements (Table 1). In the right lobe, the concentration (mean \pm standard error, $\mathrm{SE} \mu \mathrm{g} \mathrm{g}^{-1}$ ) of $\mathrm{As}, \mathrm{Zn}$, and $\mathrm{Cd}$ were $33.0 \pm 1.6,22.5 \pm 2.1$, and $15.5 \pm 0.9$, respectively; while for $\mathrm{Cu}, \mathrm{Se}, \mathrm{Hg}$, and $\mathrm{Pb}$, it was $3.2 \pm 0.3,0.5 \pm 0.1$, $0.07 \pm 0.02$, and $0.05 \pm 0.01$. In the left lobe, As and Cd's concentration was lower compared to the right lobe, while $\mathrm{Zn}$ was higher (Table 1). These results suggest a heterogeneous distribution of $\mathrm{As}, \mathrm{Zn}$, and $\mathrm{Cd}$ in the whale shark liver. Despite these differences, all trace elements' mean concentrations were not different (Mann-Whitney test $P>0.05$ ) between lobes.

It is important to highlight that in the southwest Gulf of California, around the Mogote area (Fig. 1) where feeding aggregations of $R$. typus occur, sediments are naturally enriched in $\mathrm{As}$, and $\mathrm{Cd}$, and they have been related to phosphorites present in the watershed (PérezTriboullier et al. 2015). Phosphorite mining activity in San Juan de la Costa during the past 80 years could have affected As and Cd's levels in whale shark feeding grounds, leading finally to bioaccumulation in the liver. 


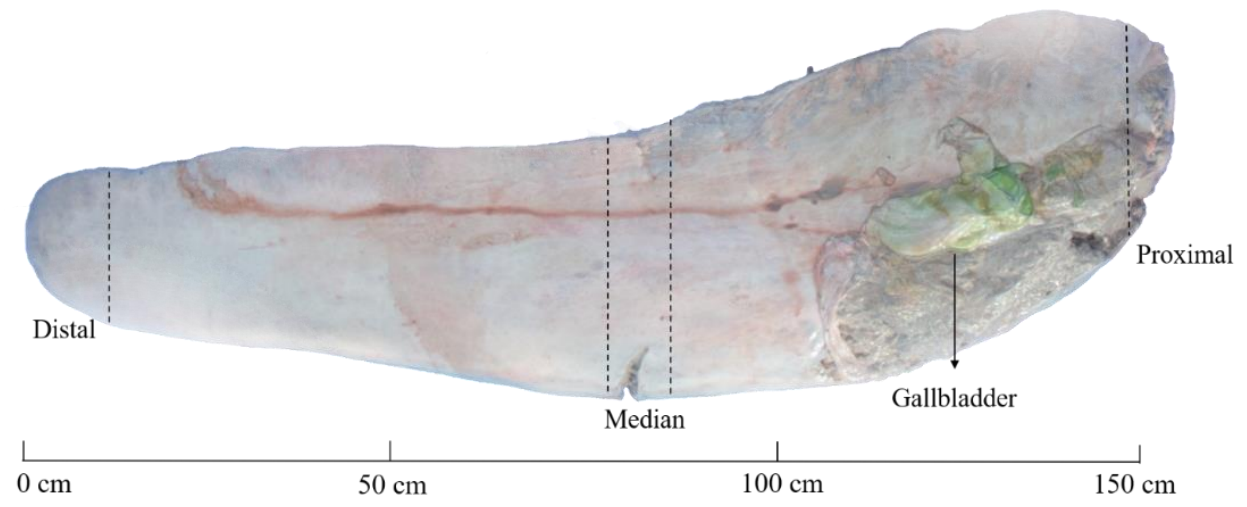

Figure 2. Rhincodon typus right lobe of the liver with the proximal, median, and distal area along with the gallbladder.

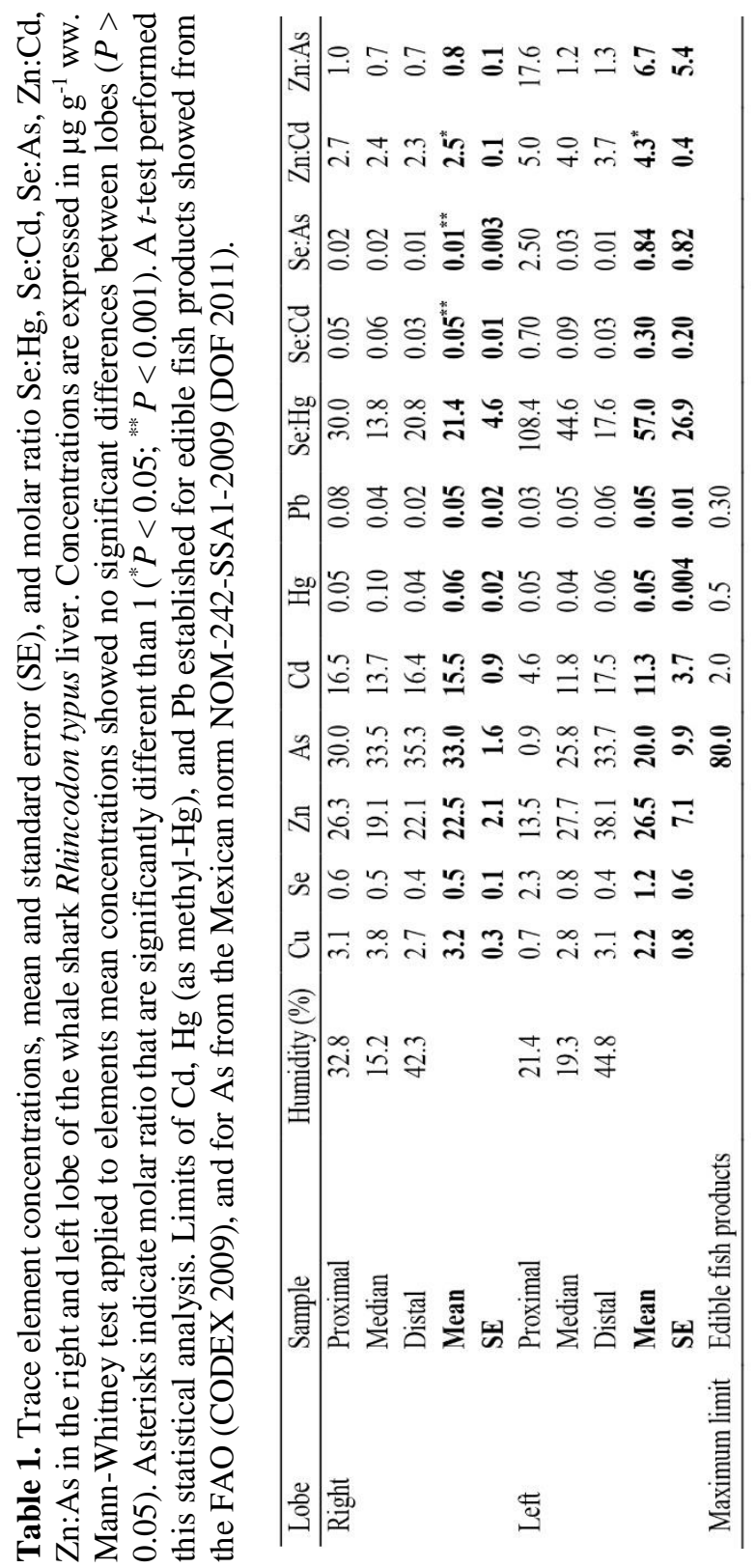

High levels of $\mathrm{Cd}$ and $\mathrm{Zn}$ in the liver of sharks have been explained by the action of metallothioneins, which are concentrated in the hepatic tissue retaining these elements (Marcovecchio et al. 1991). Conversely, $\mathrm{Cu}$, $\mathrm{Se}, \mathrm{Hg}$, and $\mathrm{Pb}$ were found in lower concentrations (Table 1). Significant differences in the right lobe were found between As with $\mathrm{Cu}$, As with $\mathrm{Se}$, and As with $\mathrm{Hg}$ concentrations, which showed a $P<0.05$ (KruskalWallis and posterior Dunn-test applied). Other significant differences $(P<0.05)$ were found between $\mathrm{Zn}$ with $\mathrm{Se}$ and with $\mathrm{Hg}$ in the same lobe. Finally, $\mathrm{Cd}$ and $\mathrm{Pb}$ concentrations and between $\mathrm{Cd}$ and $\mathrm{Hg}$ showed a $P<0.05$ (Kruskal-Wallis and posterior Dunn-test applied).

In the left lobe, $\mathrm{Zn}$ showed the highest concentrations (38.1 and $27.7 \mu \mathrm{g} \mathrm{g}^{-1}$ in distal and median, respectively), which were also higher than the same element's levels in the right lobe. Arsenic concentrations were $33.7 \mu \mathrm{g} \mathrm{g}^{-1}$ in the distal and $25.8 \mu \mathrm{g} \mathrm{g}^{-1}$ in the median area. Cd concentrations were $17.5 \mu \mathrm{g} \mathrm{g}^{-1}$ in the distal and $11.8 \mu \mathrm{g} \mathrm{g}^{-1}$ in the median area. Dunn-test applied to the mean concentrations of $\mathrm{Zn}$, As, and $\mathrm{Cd}$ showed significant differences $(P<0.05)$ with $\mathrm{Hg}$ and $\mathrm{Pb}$. Unexpectedly, $\mathrm{Zn}, \mathrm{As}$, and $\mathrm{Cd}$ was found in lower concentrations in the left lobe's proximal area $(13.5 \mu \mathrm{g}$ $\mathrm{g}^{-1} \mathrm{Zn}, 0.9 \mu \mathrm{g} \mathrm{g}^{-1} \mathrm{As}$, and $4.6 \mu \mathrm{g} \mathrm{g}^{-1} \mathrm{Cd}$ ) compared to the proximal area of the right one.

The proximal area of the right lobe of the whale shark liver is located near the gallbladder, which contains the bile. The vicinity between the proximal area and the gallbladder in the right lobe could be a factor that increases concentrations of As and $\mathrm{Cd}$. $\mathrm{Hg}$ was found in similar concentrations in the proximal area of the right $\left(0.050 \mu \mathrm{g} \mathrm{g}^{-1}\right)$ and left lobe $(0.054 \mu \mathrm{g}$ $\left.\mathrm{g}^{-1}\right)$. The $\mathrm{Hg}$ levels in both lobes were higher $(0.040$ $0.100 \mu \mathrm{g} \mathrm{g}^{-1}$ in the right lobe, and $0.040-0.058 \mu \mathrm{g} \mathrm{g}^{-1}$ in left lobe) compared to the levels reported in the liver of a dead whale shark from China $(0.00330 \pm 0.00001 \mu \mathrm{g}$ 

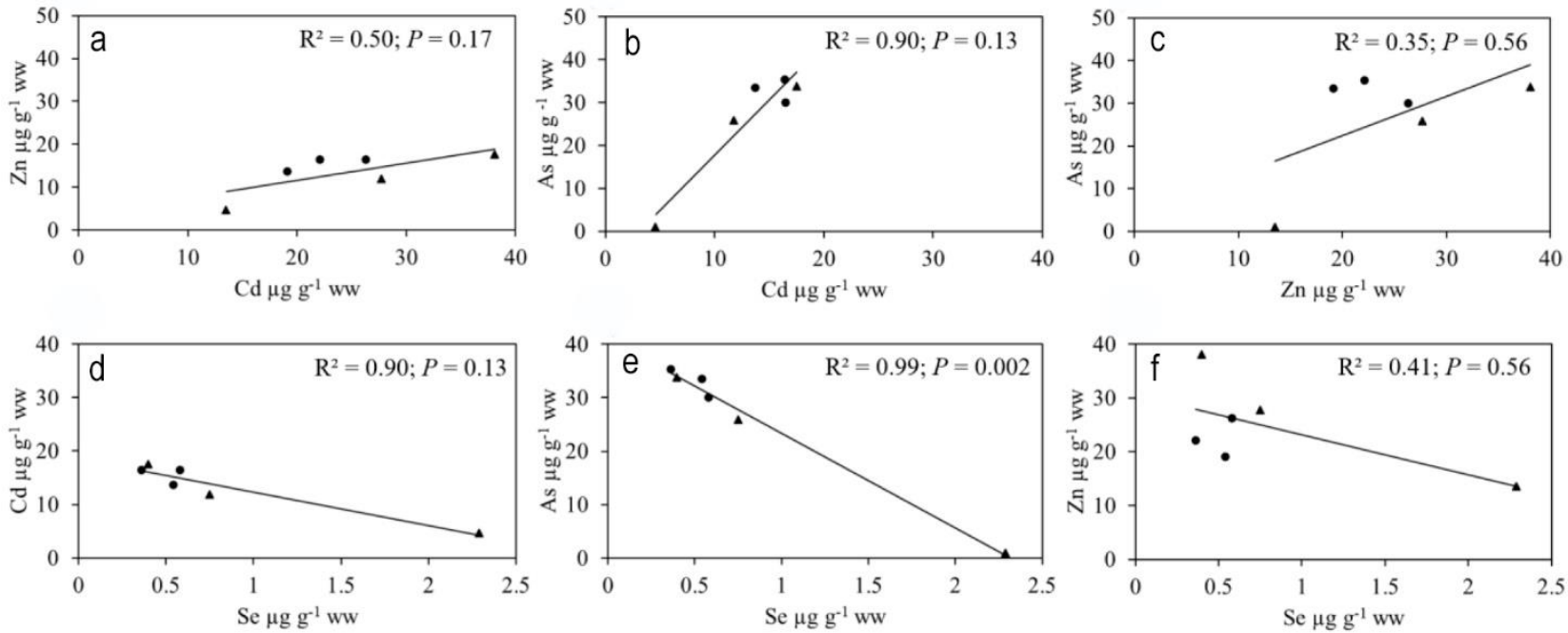

Figure 3. Trace element variation (Spearman $\mathrm{R}^{2}$ and $P$ are included) between a) $\mathrm{Zn}$ and $\mathrm{Cd}$, b) $\mathrm{As}$ and $\mathrm{Cd}$, c) $\mathrm{As}$ and $\mathrm{Zn}$, d) $\mathrm{Cd}$ and $\mathrm{Se}$, e) As and $\mathrm{Se}, \mathrm{f}) \mathrm{Zn}$ and Se. Circles represent concentrations from the right lobe and triangles from the left lobe in $\mu \mathrm{g} \mathrm{g}^{-1} \mathrm{w} / \mathrm{w}$.

$\mathrm{g}^{-1}$; Wang et al. 2015). Nevertheless, $\mathrm{Hg}$ levels found in the whale shark from La Paz were lower compared to the levels reported in the liver of the carnivorous blue shark Prionace glauca from the Mexican Pacific (0.22 $\pm 0.35 \mu \mathrm{g} \mathrm{g}^{-1}$; Barrera-García et al. 2013) or the predatory shark Sphyrna lewini from the Gulf of California (Bergés-Tiznado et al. 2015). The uptake of $\mathrm{Hg}$ principally occurs through the diet; therefore, $\mathrm{Hg}$ concentrations are expected to be higher in top predator sharks rather than filter-feeding species. Considering that the sampled shark feeds most of the time in La Paz Bay, low $\mathrm{Hg}$ concentrations in its liver indicate that the trophic base, from which the shark depends, also present low $\mathrm{Hg}$ concentration in this area.

Selenium with $\mathrm{Hg}$ and Cd's antagonist effect has been observed in several organisms, including elasmobranchs (Siscar et al. 2014). Even though these interactions' mechanism is not well understood, the molar ratio between the elements is proposed to be $1: 1$ (or close) for Se to exhibit efficient behavior against metal toxicity (Ralston et al. 2016). Se showed the highest $\left(2.3 \mu \mathrm{g} \mathrm{g}^{-1}\right)$ level in the left lobe's proximal area; consequently, molar ratio $\mathrm{Se}: \mathrm{Hg}$ in this area presented the highest value (108:1), which indicates a more evident detoxification process in this area. Molar Se: $\mathrm{Hg}$ ratio was 44.6:1 in the median area and 17.6:1 in the distal area (Table 1), indicating that these areas of the left lobe contain sufficient Se to detoxify the action of $\mathrm{Hg}$. In the right lobe, Se:Hg molar ratio was 29.6:1, 20.8:1, and 13.8:1, in the proximal, distal, and the median area, respectively, which also indicates sufficient Se to detoxify $\mathrm{Hg}$ action in the three regions.
Molar Se:Cd ratio was <1 (Table 1) in all sampled areas of the liver, suggesting that Se concentrations are not enough to protect the organ from $\mathrm{Cd}$ damage. $\mathrm{Cd}$ is a non-essential metal, and it is known to affect the uptake of calcium through fish gills (Niyogi \& Wood 2004). Also, exposure to this element may lead to the accumulation of reactive oxygen species and oxidative damage (Waisberg et al. 2003, Bertin \& Averbeck 2006). In contrast, results show that the molar $\mathrm{Zn:Cd}$ ratio was $>1$ (Table 1 ), which shows that in the whale shark, $\mathrm{Zn}$ might exert a more effective detoxification action against $\mathrm{Cd}$ concerning Se. These same results have been found in the liver of deep fish species (Siscar et al. 2014) and mammals (Jihen et al. 2009), where Zn is more efficient than $\mathrm{Se}$ in protecting the liver from $\mathrm{Cd}$ damages. The molar ratio Se:As was $<1$ in all sampled areas of the liver except in the left lobe's proximal area, while the molar ratio $\mathrm{Zn}$ :As was close to or greater than 1 (Table 1). According to these results, $\mathrm{Zn}$ could also act more efficiently against As concerning Se. An antagonistic effect of $\mathrm{Zn}$ over As has been observed in the cladoceran Daphnia obtusa (Gaete \& Chavez 2008); however, information about the antagonistic effect of $\mathrm{Se}$ and $\mathrm{Zn}$ on As is scarce. Spearman correlation applied to trace elements shows strong relations (Figs. 3b,d,e). The antagonism between Se and As in whale shark liver (right and left lobe) is shown in Figure 3e, where Spearman correlation shows a negative and significant $\left(\mathrm{R}^{2}=0.989 ; P=0.002 ; \mathrm{n}=\right.$ 6) correlation between these elements. A negative $\left(\mathrm{R}^{2}\right.$ $=0.903)$ and not significant $(P=0.136 ; \mathrm{n}=6)$ Spearman correlation was also found between Se and Cd (Fig. 3d). The highest concentration of Se $(2.30 \mu \mathrm{g}$ 
$\mathrm{g}^{-1}$; Table 1) found in the whale shark liver corresponds to the lowest concentrations of $\mathrm{Cd}\left(4.63 \mu \mathrm{g} \mathrm{g}^{-1}\right)$ and As $\left(0.88 \mu \mathrm{g} \mathrm{g}^{-1}\right)$, which indicate antagonism.

In conclusion, trace elements analyzed were not uniformly distributed in the whale shark liver; $\mathrm{Cd}$, As, and $\mathrm{Zn}$ were found in high concentrations in both right and left lobes, probably due to natural enrichment of the area associated with remains of phosphorites. In contrast, $\mathrm{Hg}$ and $\mathrm{Pb}$ were found in lower concentrations. The left lobe proximal area presented the lowest concentrations of $\mathrm{Zn}$, As, and $\mathrm{Cd}$, and the highest Se concentrations, which could be due to the gallbladder's reduced distance, which is connected to the right lobe or a detoxification action from $\mathrm{Se}$ throughout the action of selenoproteins. Molar ratio $\mathrm{Se}: \mathrm{Hg}$ indicates sufficient Se levels to detoxify $\mathrm{Hg}$ in the lobes. On the other hand, the molar ratio $\mathrm{Zn}$ :Cd was $>1$, which shows that $\mathrm{Zn}$ acts more efficiently in $\mathrm{Cd}$ detoxification in this species. Whale shark means concentrations of $\mathrm{Cd}$ found in both lobes of the liver (Table 1) exceeded the maximum levels established by the FAO in edible fish products $\left(2.0 \mu \mathrm{g} \mathrm{g}^{-1} \mathrm{ww}\right.$; CODEX 2009). Conversely, $\mathrm{Hg}$ and $\mathrm{Pb}$ concentrations found in the liver were lower than the maximum levels established in the CODEX (2009) (Hg (as methyl-Hg $\left.0.5 \mu \mathrm{g} \mathrm{g}^{-1}\right)$; $\mathrm{Pb}: 0.3 \mu \mathrm{g} \mathrm{g}^{-1} \mathrm{ww}$ ); similarly, as levels were below the maximum established by the Mexican norm NOM-242-SSA1-2009 (80 $\mu \mathrm{g} \quad \mathrm{g}^{-1}$, DOF 2011). Although the whale shark is not an edible fish in Mexico and most of the world, its relatively high $\mathrm{Cd}$ level is remarkable, which would have to be considered if the liver of this animal were considered for human consumption.

\section{ACKNOWLEDGMENTS}

We want to thank H. Bojórquez-Leyva and C. JocobiAguilar for the analytical support, as well as the Instituto Politécnico Nacional for the support of the Contracting Excellence Program and Fellowship EDI and COFAA. Thanks to CONANP, PROFEPA and to CONACYT for the scholarship and to the CICIMAR Projects SIP 20181417 and SIP 20170585 and INFRACONACYT 230061. Investigation funded by the Project IN200619 (DGAPA-PAPIIT-UNAM) titled "Metales y metaloides en ríos y presas de cuencas mineras de Sinaloa: identificando contaminación y riesgos para la salud".

\section{REFERENCES}

Barrera-García，A., O’Hara，T., Galván-Magaña， F., Méndez-Rodríguez, L.C., Castellini, M. \& ZentenoSavín, T. 2013. Trace elements and oxidative stress indicators in the liver and kidney of the blue shark (Prionace glauca). Comparative Biochemistry and Physiology - Part A: Molecular \& Integrative Physiology, 165: 483-490.

Belzile, N., Wu, G.J., Chen, Y.W. \& Appanna, V.D. 2006. Detoxification of selenite and mercury by reduction and mutual protection in the assimilation of both elements by Pseudomonas fluorescens. Science of the Total Environment, 367: 704-714.

Bergés-Tiznado, M.E., Márquez-Farías, F., LaraMendoza, R.E., Torres-Rojas, Y.E., Galván-Magaña, F., Bojórquez-Leyva, H. \& Páez-Osuna, F. 2015. Mercury and selenium in muscle and target organs of scalloped hammerhead sharks Sphyrna lewini in the SE Gulf of California: dietary intake, molar ratios, loads and human health risks. Archives of Environmental Contamination \& Toxicology, 69: 440452.

Bertin, G. \& Averbeck, D. 2006. Cadmium: cellular effects, modifications of biomolecules, modulation of DNA repair and genotoxic consequences (a review). Biochimie, 88: 1549-1559.

Bosch, A.C., O'Neill, B., Sigge, G.O., Kerwath, S.E. \& Hoffman, L.C. 2016. Heavy metal accumulation and toxicity in smoothhound (Mustelus mustelus) shark from Langebaan Lagoon, South Africa. Food Chemistry, 190: 871-878.

Codex Alimentarius Commission (CODEX). 2009. Codex Stan 193-1995. General standard for contaminants and toxins in food and feed. International Food Standard. FAO, Rome. [http://www.fao.org/fileadmin/user_ upload/livestockgov/documents/1_CXS_193e.pdf]. Reviewed: September 3, 2020.

Colman, J.G. 1997. A review of the biology and ecology of the whale shark. Journal of Fish Biology, 51: 12191234.

Correa, L., Rea, L.D., Bentzen, R. \& O'Hara, T.M. 2014. Assessment of mercury and selenium tissular concentrations and total mercury body burner in 6 Steller sea lion pups from the Aleutian Islands. Marine Pollution Bulletin, 82: 175-182.

Diario Oficial de la Federación (DOF). 2011. Norma oficial mexicana NOM-242-SSA1-2009, productos y servicios. Productos de la pesca frescos, refrigerados, congelados y procesados. Especificaciones sanitarias y métodos de prueba. [http://www.dof.gob.mx/normasOficiales/4295/ salud2a/salud2a.htm]. Reviewed: September 3, 2020.

Endo, T., Haraguchi, K., Hotta, Y., Hisamichi, Y., Lavery, S., Dalebout, M.L. \& Baker, C.S. 2005. Total mercury, methyl mercury, and selenium levels in the red meat of small cetaceans sold for human consumption in Japan. Environmental Science \& Technology, 39: 5703-5708. 
Gaete, H. \& Chávez, C. 2008. Evaluación de la toxicidad de mezclas binarias de cobre, cinc y arsénico sobre Daphnia obtusa (Kurz, 1874) (Cladocera, Crustacea). Limnetica, 27: 1-10.

Hinton, D.E., Segner, H. \& Braunbeck, T. 2001. Toxic responses of the liver. In: Schlenk, D. \& Benson, W.H. (Eds.). Target organ toxicity in marine and freshwater teleosts. CRC Press, London.

Ketchum, J.T., Galván-Magaña, F. \& Klimley, A.P. 2013. Segregation and foraging ecology of whale sharks, Rhincodon typus, in the southwestern Gulf of California. Environmental Biology of Fishes, 96: 779795.

Jamwal, A., Lemire, D., Driessnack, M., Naderi, M. \& Niyogi, S. 2018. Interactive effects of chronic dietary selenomethionine and cadmium exposure in rainbow trout (Oncorhynchus mykiss): a preliminary study. Chemistry, 197: 550-559.

Jihen, E.H., Imed, M., Fatima, H. \& Abdelhamid, K. 2009. Protective effects of selenium (Se) and zinc ( $\mathrm{Zn})$ on cadmium $(\mathrm{Cd})$ toxicity in the liver of the rat: effects on the oxidative stress. Ecotoxicology and Environmental Safety, 72: 1559-1564.

Marcovecchio, J.E., Moreno, V.J. \& Pérez, A. 1991. Metal accumulation in tissues of sharks from the Bahía Blanca estuary, Argentina. Marine Environmental Research, 31: 263-274.

Mieiro, C.L., Pacheco, M., Pereira, M.E. \& Duarte, A.C. 2011. Mercury organotropism in feral European sea bass (Dicentrarchus labrax). Archives of Environmental Contamination and Toxicology, 61: 135-143.

Nelson, J.D. \& Eckert, S.A. 2007. Foraging ecology of whale sharks (Rhincodon typus) within Bahía de Los Angeles, Baja California Norte, Mexico. Fisheries Research, 84: 47-64.

Niyogi, S. \& Wood, C.M. 2004. Kinetic analyses of waterborne $\mathrm{Ca}$ and $\mathrm{Cd}$ transport and their interactions in the gills of rainbow trout (Oncorhynchus mykiss) and yellow perch (Perca flavescens), two species differing greatly in acute waterborne Cd sensitivity. Journal Comparative Physiology - Part B: Biochemistry \& Molecular Biology, 174: 243-253.

Pancaldi, F., Galván-Magaña, F., González-Armas, R., Soto-Jiménez, M.F., Whitehead, D.A., O'Hara, T., et al. 2019a. Mercury and selenium in the filter-feeding whale shark (Rhincodon typus) from two areas of the Gulf of California, Mexico. Marine Pollution Bulletin, 146: 955-961.

Received: April 6, 2020; Accepted: November 10, 2020
Pancaldi, F., Páez-Osuna, F., Soto-Jiménez, M.F., GonzálezArmas, R., O'Hara, T., Marmolejo-Rodríguez, A.J., et al. 2019b. Trace elements in tissues of whale sharks (Rhincodon typus) stranded in the Gulf of California, Mexico. Bulletin of Environmental Contamination and Toxicology, 103: 515-520.

Pérez-Triboullier, H., Shumilin, E. \& RodríguezFigueroa, G.M. 2015. Trace elements in the marine sediments of the La Paz Lagoon, Baja California Peninsula, Mexico: pollution status in 2013. Bulletin of Environmental Contamination and Toxicology, 95: 61-66.

Pethybridge, H., Cossa, D. \& Butler, E.C.V. 2010. Mercury in 16 demersal sharks from southeast Australia: biotic and abiotic sources of variation and consumer health implications. Marine Environmental Research, 69: 18-26.

Ralston, N.V.C., Ralston, C.R. \& Raymond, L.J. 2016. Selenium health benefit values: updated criteria for mercury risk assessments. Biological Trace Elements Research, 171: 262-269.

Siscar, R., Koenig, S., Torreblanca, A. \& Solé, M. 2014. The role of metallothionein and selenium in metal detoxification in the liver of deep-sea fish from the NW Mediterranean Sea. Science of the Total Environment, 466-467: 898-905.

Waisberg, M., Joseph, P., Hale, B. \& Beyersmann, D. 2003. Molecular and cellular mechanisms of cadmium carcinogenesis. Toxicology, 192: 95-117.

Wang, Y., Zhang, W. \& Chen, M. 2015. Contents and evaluation of heavy metals in whale shark from China's eastern coast. WIT Transactions on Ecology and the Environment, 189: 387-397.

Whitehead, D., Galván-Magaña, F., Soto-López, K., Juaristi-Videgaray, D., Cervantes-Gutiérrez, F. \& Becerril-García, E.E. 2019. First description of a deceased juvenile whale shark Rhincodon typus in $\mathrm{La}$ Paz Bay, Mexico with comments on morphometry and age estimates. Latin American Journal of Aquatic Research, 47: 575-579. 